\title{
SIRIK DAN WASILAH DALAM AL-QUR'AN \\ Sebuah Kajian Syar'iyyah Berdasarkan Metode Tafsir Maudhu'i
}

Oleh : M. Nasri Hamang

\begin{abstract}
ABSTRAK
Syirik merupakan virus teologik yang paling berbahaya. Dalam al-Qur'an kata Syirik diitsbatkan sebagai sesesat-sesat kesesatan, sebesar-besar dosa besar dan seagungagung kejaliman. Syirik dapat beraktual besar Syirik (al-Syirik al-Akbar), syirik kecil (alSyirik al-Ashgar) dan syirik tersembunyi (al-Syirik al-Khafiy).

Dalam aktualisasi keagamaan umat, seringkali seseorang melakukan berbagai bentuk amalan yang dipa-hami dan diyakininya sebagai wasilah yang bersifat dan bernilai ibadah, yang dapat mendekatkan diri kepada Tuhan Rabbul 'Alamin, padahal sesungguh-nya tidak termasuk bentul wasilah yang diajarkan Islam dalam rangka taqarrub ilallah, bahkan boleh jadi tergolong sebuah tindakan syirik.
\end{abstract}

\section{PENDAHULUAN}

Sejarah panjang keyakinan umat manusia, amat diwarnai unsur-unsur syirik. Bukan hanya fakta-fakta abad kini yang menunjukkan hal itu, misalnya bagaimana masyarakat, terutama anak- anak sekolah Korea Utara tiap hari ramai menziarahi patung Kim II Sung di pinggiran Kota Pyongyang untuk meminta berkah. Dan bagaimana masyarakat Moskow yang tiap hari ramai juga menziarahi patung Mousoleum Lenin dila-pangan Merah Moskow untuk memin-ta juga berkah, bahkan patung Stalin diperlakukan seperti Tuhan. Serta bagaimana masyarakat Republik Rakyat China berlaku sebagaimana masyarakat Korea Utara dan Moskow tersebut terhadap Mao Tze Dong atau Mao Tse Tung.'

Akan tetapi Alqur'an pun sendiri menggambarkan bagaimana syirik telah menjadi kecenderungan umat-umat atau masyarakat terdahulu tersebut menimbulkan hipotesis, bahwa umat masyarakat manusia tidak tahu menahu mengenai syirik serta dampaknya terhadap diri dan kehidupan, baik duniawi maupun ukhrawi.

Kita bangsa Indonesia dalam me-nyahuti akan hal tersebut, sejak awal kemerdekaan, melalui The Founding Father's menetapkan Pancasila sebagai dasar negara dengan silanya 
yang pertama berisikan "Penafian Syirik", yaitu Ketuhanan Yang Maha Esa, dan selan-j utnya lebih dipertegas dalam GBHN (Garis-Garis Besar Haluan Negara), bahwa pembangunan nasional berasaskan iman dan takwa serta Agama merupakan landasan etik bagi pembangunan nasional. $^{3}$

Dalam makalah ini akan dibahas tiga aspek ; yaitu pertama, apakah sebenarnya syirik $i t u$ ?, kedua, sejauhmana pentingnya manjauhi syirik, dan ketiga, sejauhmana peranan wasilah dalam menjauhkan syirik.

\section{PENGERTIAN SYIRIK}

Secara etimologis, syirik yang berakar fi'il madhi ( 1 y) yang dalam mu jam maqayis al-Lughah terdiri atas huruf-huruf syin, ra' dan kaf mempunyai dua makna asli. Pertama ; bermakna per-bandingan atau perselisihan individu, dan kedua bermakna terbentang dan lurus. ${ }^{4}$

Adapun yang dimaksud makna pertama ialah sesuatu diantara dua yang salah satunya tidak bisa menyendiri diantara keduanya, misalnya dikatakan, saya bersekutu si Fulan.' Sedangkan yang dimaksud makna kedua ialah menutup jalan yang berarti bersekutu pula, seperti bersekutunya sandal yang serupa. ${ }^{6}$

Dalam kamus al-Munawwir, syirik berarti (kemusyrikan, menduakan Tuhan).' Secara terminologis, al-Maraghiy membagi syirik ke dalam dua macam ; yaitu, pertama syirik uluhiyah, adalah perasaan akan adanya kekuasaan lain selain Allah dibelakang sebab-sebab dan sunnah-sunnah alam. ${ }^{8}$ Kedua, syirik rubibiyah, adalah menjadikan sebagian hukum-hukum Agama yang berupa penghalalan dan pengharaman sebagian manusia dengan meninggalkan wahyu.9 Menurut Harifuddin Cawidu, para ulama dengan melihat syirik dari segi intensitasnya, membaginya ke dalam dua macam, yaitu syirik besar (syirik akbar) dan syirik kecil (syirik ashgar), ${ }^{I^{\circ}}$

Adapun yang dimaksud syirik be-sar, yang disebut juga syirik terang-terangan (syirik ialah mempersekutukan dengan menjadikan sesuatu selain Allah sebagai sembahan, objek pemujaan dan atau tempat menggantungkan harapan dan dambaan." Sedang yang dimaksud syirik kecil yang disebut juga dengan syirik tersembunyi (syirik al-khafiy), ialah melaku-kan suatu perbuatan, khususnya yang ber-kaitan dengan amalan-amalan keagamaan, bukan atas 
dasar keikhlasan untuk menca-ri ridha Allah, melainkan karena tujuan-tujuan lain yang bersifat keduniaan. ${ }^{12}$ Syirik kecil ini disebut juga riya."

Nurcholis Madjid berpandang-an, bahwa syirik bukan hanya sikap seseorang yang mengagung-agungkan sesuatu dari kalangan sesama makhluk ini, termasuk sesama manusia (kultus), tetapi syirik juga meliputi sikap mengagungkan diri sendiri kemudian menindas harkat dan martabat sesama manusia, seperti tingkah para dikatator dan tiran. Keduanya adalah sikap melawan Allah, yaitu kebenaran mutlak, dan berlawanan dengan jalan hidup menuju perkenan (ridha) Allah Yang Maha Benar itu. Walaupun demikian, yang banyak disinggung Alqur'an adalah jenis syirik besar, khusunya dalam bentuk wathasanniyat (keberhalaan).' 6

\section{PENTINGNYA MENJAUHI SYIRIK (BAHAYA-BAHAYA SYIRIK)}

Dalam Alqur'an Surah al-Nisa (4) ayat 48 dan 116, Tuhan berfinnan yang artinya Sesungguhnya Allah tidak akan men gampuni dosa syirik, dan Dia mengampuni segala dosa yang selain dari (syirik) itu, bagi siapa yang di-kehendaki-Nya. Barang siapa yang mempersekutukan Allah, maka sungguh ia telah berbuat dosa yang besar. Sesungguh-nya Allah tidak mengampuni dosa mempersekutu-kan (sekutu) dengan Dia, dan Dia meng-ampuni dosa selain dari syirik itu bagi siapa yang dikehendaki -Nya. Barang siapa yang mempersekutukan (sesuatu) dengan Allah, maka sesung guhnya ia telah teresesat sejauh-jauhnya. ${ }^{17}$

Berdasarkan asbah nuzu ayat tersebut, bahwa syirik yang dimaksudkan adalah kemusyrikan yang disamping menserikatkan Allah, melakukan juga sifat-sifat kemunafikann dan Al-Maraghiy mengatakan, bahwa Nabi saw. Menafsirkan dalam ayat tersebut, adalah perhuatan yang mengadakn tuhan-tuhan selain Allah dengan jalan mcrumuskan hukumhukum halal dan haram tersendiri untuk ditaati.

Dengan demikian macam syirik yang dimaksudkan adalah syirik Akbar, tidak termasuk ("sham-, sebagaimana juga dimaksud ayat berikutbnya (117) yang artinya Yang mereka sembah selain Allah, tidak lain hanya berhala. dengan menyembah berhala itu. mereka tak lain hanyalah menyembah syaitan-syaitan.'

Ketiga ayat tersebut menggambarkan secara jelas dan tegas. bahwa betapa perbuatan syirik itu akan menimbulkan dampak yang, amat berbahaya bagi kehidupan keagamaan berupa antara lain ; pertama, tidak mendapatnya pengampunan dari Allah, sebagaimana permulaan ayat mengatakan, bahwa tidak diampuni-nya dosa syirik karena akibatnya dapat 
merusak diri. ${ }^{21}$ Kedua, tergolong dosa yang amat besar. sebagaimana penutup bahkan sebesarbesarnya dosa besar, sebagaimana hadist Nabi saw. Dari Anas bin Malik r.a berkata Rasulullah saw. Bersabda : Telah dikemukakan kepada Rasulullah saw. (ditanyaiNya) tentang dosa-dosa besar, lalu Rasulullah saw. Bersabda : syirik kepada Allah, membunuh jiwa, dan durhaka kepada kedua ibu-bapak. (al-Buchary). Ibnu Katsir mengatakan, bahwa syirik digolongkan dosa besar, sebab perbuatan syirik menyamakan kedudukan Tuhan yang hanya dari dialah semua nikmat dengan berhala-hala yang tidak memiliki nikmat.

Ketiga, sesesat-sesat kesesatan, sebagaiman penutup ayat 116, al-Maraghiy mengatakan, bahwasahnya orang-orang yang melakukan perbuatan syirik itu telah tersesat dari tujuan atau terjauh dari jalan lurus, sebab syirik merupakan kesesatan yang merusak akal, menodai kejernihan ruh, dan menjadikannya tunduk kepada hamba lain seperti dirinya sendiri." Keempat, penyembahan terhadap syaitan, sebagaimana penutup ayat 117, al Maraghiy mengatakan, diantara pekerjaan dan tuntutan tabiat setan ialah menyesatkan dan menyibukan para hamba dengan anganangan kososng yang bathil (jauh dari haq dan hidayah) seperti penye-satannya kepada hamba (manusia) yang berpen-dapat, bahwa orang-orang berdosa akan mendapatkan Rahmat Allah tanpa bertaubat dan akan keluar dari neraka setelah mendapatkan Syafaat, serta membujuk manusia untuk senang dunia dan lupa akhirat." Dan Kelinia, Kezaliman yang besar, sebagaimana penutup ayat 13 surah Lugman (13), (Sesungguhnya mempersekutukan (Allah) adalah benar-benar kezalima yang besar).

Demikian ayat berbahayanya atau perlunya menjauhi perbuatan syirik itu, sehingga Allah mengulanginya dalam surah yang sama dan dengan antar ayat yang agak berdekatan dan bunyi yang hampir sama, harapkan bantuan untuk dapat menyelesaikan suatu pekerjaan yang tidak sanggup diselesaikan dengan tenaga sendiri.

Misalnya juga salah satu bacaan doa iftitah yang sebagian matanya diambil dari surah alAn 'am (6) ayat 162 dan 163 yang artinya: Katakanlah : Sesungguhnya shalatku, ibadatku, hidupku dan matiku hanyalah untuk Allah, Tuhan semesta alam. Tiada sekutu bagi-Nya, dan demikian itulah yang diperintahkan kepadaku dan aku adalah orang yang pertama-tama menyerahkan diri (kepada Allah). ${ }^{37}$ 


\section{B. Ibadah Haji}

Dalam Alqur'an al-Hajj (22) ayat 33 Allah berfman yang artinya: Bagi kamu pada bintang-bintang hadyu, itu ada beberapa manfaat sampai kepada waktu yang ditentukan, kemudian tempat wajib (serta akhir masa) menyembelihnya ialah setelah sampai ke Baitul Atiq (Baitullah). ${ }^{38}$

Menurut Team Terjemah/ Tafsir Dep. Agama RI, bahwa yang dimaksud dengan ialah binatang (unta, lembu, kambing dan biri-biri) yang dibawa ke Ka'bah unuk mendekatkan diri kepada Allah, binatang-binatang mana disembelih di tanah haram dan dagingnya dihadiahkan kepada fakir miskin dalam rangka ibadah haji. ${ }^{39}$

Sedangkan al-Thabariy yang dikutip dari Muhammad bin Musa dan ulama lain mengemukakan, bahwa yang

dimaksud dengannya ialah perbuatan yang diperintahkan Allah berupa manasik haji atau meng-habiskan hari-hari haji sesuai manasik haji itu sendiri, antara lain thawaf..$^{4^{\circ}}$ Adapun alQurthubiy berpandangan, bahwa binatang hadyu yang disembelih itu lebih melambangkan suatu isyarat atau ibarat akan suatu kenikrnatan yang tercabut, karena itu, tidak bernilai hadiah dan tidak beroleh pahala. Dalam hubungan ini yang dituntut adalah $i$ 'tikaf di masjid. ${ }^{4}$ Namun demikian, baik dalam untuk penyembelihan binatang hadyu untuk dihadiahkan kepada fakir-miskin, thawaf maupun $I^{\prime}$ tikaf di masjid, pada dasamya mempunyai maksud yang sama, yakni sebagai wasilah yang dengannya sekaligus dapat membersih-kan akiclah dari unsur-unsur syirik.

\section{Mahon Syafaat}

Memohon Syafaat dalam rangka wasilah terhadap Allah diisyaratkan dalam beberapa hadis, antara lain : Dari Abdullah bin Umar bin Ash, bahwasanya ia mendengar nabi saw. Bersabda : Apabila kalian mendengarkan orang menyerukan adzaan, maka ucapkanlah seperti apa yang diucapkan, sesudah itu bacalah shalawat untukku, sebab orang yang bershalawat untukku satu kali, ia akan mendapat rahmat Allah sepuluh kali. Kemudian mintalah untukku wasilah, sesungguhnya wasilah itu, adalah satu kedudukan dalam surga yang hanya patut bagi salah seorang hamba Allah. Dan aku berharap, akulah hamba Allah yang mendapat wasilah itu, karena itu, barang siapa memintakan wasilah untukku, ia akan memperoleh syafaat. 
Dari Jabir bin Abdillah, bahwasanya Rasulullah saw. Bersabda Barang siapa mengucapkan ketika mendengar adzan; ya Allah pemilik seruan yang sempurna ini dan shalat yang tegak, berilah Nabi Muhammad saw. wasilah dan keutamaan, dan bangkitkanlah dia pada tempat yang terpuji yang Engkau telah janjikan, ia akan mendapatkan syafaatku kelak pada hari kiamat.

Ibnu Asakir menasehatkan : Perbanyaklah kalian akan shalawat atasku, karena sesungguhnya shalawat kalian atasku menjadi sarana pengampun dosadosa kalian dan carilah derajat dan wasilah itu, karena sesungguhnya wasilahku menjadi syafaat bagi kalian. Gisan Hamdun mengemukakan sebagai berikut :Wasilah itu ialah apa yang mendekatkan kepada Allah berupa ketaatan. Wasilah itu juga adalah suatu pengetahuan tentang ketinggian kedudukan dalam surga, yakni kedudukan Rasulullah saw. dan tempatnyadalam surga yang berdekatan dengan 'arsy.

Berdasarkan hadis-hadis dan pemandangan ulama tersebut, tergambar dengan jelas, bahwa wasilah yang memungkinkan sekali untuk memperoleh syafaat dan surga adalah shalawat atas Nabi Muhammad saw.. al-Maraghiy mengomentari hadis-hadis tersebut seba-gai berikut. Barang siapa yang berdoa kepada Allah agar wasilah itu diberikan kepada Nabi Muhammad saw., Nabi Muhammad saw. akan membalasnya dengan svafaat, yang artinya doa juga, dan balasan itu setimpal dengan amalnya. ${ }^{46}$

Dengan memunasabahkan ayatayat sebelumnya, al-Maraghiy memberikan pengertian bahwa di sini Allah menyeru kaum mukmin bertaqwa kepada Allah dan mencari jalan yang dapat mendekatkan diri kepada-Nya dengan melaksanakan aural shaleh, dan jangan sampai terpedaya oleh agama mereka, sebagaimana yang dialami oleh orang-orang Ahli Kitab. ${ }^{47}$

Adapun meminta svafaca itu, dari segi kepahalaan dan kemakhulcm-nya, dapat dicermati hadis berikut :Dari Abu Musa berkata : Rasulullah saw. bersabda. Bersyafaatlah kalian kepadaku agar kalian mendapat pahala kiranya Allah memutuskan sesuai bahasa NabiNya apa yang dikehendaki. Abu Daud.

Dari Muawiyah berseru : Bersivftratlah kalian, agar supaya kalian mendapat pahala, karena sesungguhnya aku tidak menyukai perkara yang diperlambat, sebagaimana kalian bersyafaat, lalu kalian mendapat pahala, karena sesungguhnya Rasulullah saw. bersabda : Bersycifitatlah kalian, kalian akan mendapat pahala. 
Muhammad Syams al-Haq mengemukakan syarah hadis tersebut sebagai berikut : Apabila seseorang yang punya hajat, lalu mengemukakan hajatnya kepadaku, hendaklah kalian ber.s:vcrfacit baginya kepadaku, karena sesungguhnya jika kalian bersycifilat, kalian akan memperoleh pahala sebagaimana saya akan menerima syafaat kalian atau tidak. Akan tetapi, kata tidak disini, bukan berarti tidak akan mendapat pahala dan syafaat, melainkan sebaliknya, yakni akan diterima. Namun perlu diyakini, bahwa diterima atau tidak, adalah suatu tagdir.)

Demikianlah isyarat-isyarat bentuk permohonan .syafaat yang diajarkan Nabi saw. (Islam). dengan pemahaman, bahwa perrnohonan .syafaat tidak dibenarkan ditujukan kepada makhluk apapun dan siapapun, melainkan hanya kepada Allah. Rasyid menegaskan, bahwa Alqur'an menetapkan akan syafaat semata-mata milik Allah, monopoli Allah, karena itu tidak seorangpun yang berhak memberi syafaat disamping-Nya, kecuali atas izin-Nya sebagaimana petunjuk Q.S. al-Anbiya' (21) ayat 28 dan 29.51.

Dengan pemahaman dan praktek svafaat seperti tersebut, secara mutlak akan membentuk pelakunya terjauh dari syirik.

\section{KESIMPULAN}

Syirik merupakan refleksi jiwa, akal, dan fisik dalam menyekutukan Allah yang mungkin dalam bentuk eksiernal, yakni demonstratif yang dapat disaksikan oleh orang lain, dan internal,. yakni yang hanya dirasakan oleh yang bersangkutan.

Bentuk eksternal dan internal syirik dapat berupa paganislik (penyembahan berhala) dengan segala macam wujud apa saja yang dijadikan objek sekaligus subjek pagani.sme itu, yang dalam isyarat Alqur'an (dan istilah ulama) disebut syirik akbar.

Svirik tidak diragukan sebagai perbuatan yang membawa implikasi kehidupan keagamaan yang amat berbahaya sebab indikasi-indikasinya yang tak terampuni, sebesar-besar dosa besar, sesesatsesat kesesatan, penyembahan syaitan, dan kezaliman yang besar.

Dalam upaya membersihkan akidah dari unsur-unsur syirik perlu melakukan berbagai amalan wasilah, yaitu amalanamalan yang memungkinkan untuk mendekatkan diri kepada Allah, antara lain, ibadah shalut, ibadah haji, dan mohon syafaat.

Dengan melaksanakan amalanamalan wasilcrh tersebut secara maksimal, baik kuantitas maupun kualitas mutlak akan membentuk pribadi pelakunya bebas dari faktor syirik seraya menemukan akidahnya yang murni, yakni akidah tauhid atau akidah kldish. 


\section{CATATAN KAKI :}

1. Lihat Nurcholis Madjid, Pintu-Pintu Mentnu Tuhan, (Cet. I ; Jakarta : Paramadina, 1994), hal 36-37.

2. Lihat Qur'an, misalnya S. al-Nahl (16) : 36, S. al-Anbtva (2/) : 25 dan S. al-Hijr (15) : 94 .

3. Lihat Deppen, GBHN 1998 dan 1993.

4. Lihat Abi al-Husain, Mu,jam Magayis alLughah. Juz III, (Beirut : Dar al-Fikr, t.th), hal 265.

5. Lihat /hid.

6. Lihat ibid.

7. Lihat Ahmad Watson, Kamus alMunawwir, (Yogyakarta : Pondok Pesantren alMunawwir, 1984), h. 765..

8. Lihat Bahrun Abubakar, Tafis alMaraghiy., Jilid VI, (Cet. I ; Semarang : Toha Putera, 1987), h. 96.

9. Lihat Ibid.

10. Lihat Harifuddin Cawidu, Konsep Kufur Dalam Al-Qur'an, (Cet. I ; Jakarta : Bulan Bintang, 1991), h. 135.

11. Lihat Ibid.

12. Lihat Ibid.

13. Lihat Ibid.

14. Lihat Nurcholis Madjid, Op. Cit., h.11.

15. Lihat Ibid.

16. Lihat Harifuddin Cawidu, loc. Cit.

17. DepagRI, Al-Qur'an dan

Terjemahannya, (Jakarta : Yayasan Penyelenggara Penterjemah/ Pentafsiran Al-Qur'an, 1971), h. 126 dan 141.

18. Lihat Qamaruddin Shaleh, Asbabun Nuzul, (Cet. II ; Bandung : Diponegoro, 1975), h. 131-132.

19. Lihat Abu Bakar, Op. Cit., h. 266.

20. Depag RI, Loc. Cit.

21. Lihat Bahrun Abubakar, Op.Cit., h. 98

22. al-Buchariy, Shahih al-Buchany, Juz VII, (Cet. I ; Beirut : Dar al-Ilmiyyah, 1992), 
h. 93. bunyi hadis yang lain dapat dilihat pada h. 94 .

23. Ibnu Katsir, TafSir al-Qur'an al-Azhim, Juz III, (Cet. I ; Beirut : Syirkah Maktabah wa al-Mathba'ah al-Babiy alHalabiy, 1992), h. 428.

24. Lihat Bahrun Abubakar, Op. Cit., h. 264

25. Lihat Harifuddin Cawidu, Ibid., h. 266

26. Dep. Agama RI, Op. Cit., h. 654.

27. Lihat Bahrun Abubakar, Op. Cit., h. 266

28. Lihat Ibid., h. 263

29. Lihat Ibid.

30. Depag RI, Op. Cit., h. 165

31. Lihat Abi al-Husain, Op. Cit., h. 110

32. Lihat Ahmad Warson, Op. Cit., h. 1664

33. Lihat Bahian Abubakar, Op. Cit., h. 191.

34. Lihat Ibid. h. 192.

35. Depag RI, Op. Cit., h. 6

36. Ibid.

37. Ibid., h. 216. Lihat juga hadis mengenai bacaan doa iftitah dalam Kitab-Kitab Hadis (Bab shalat).

38. Ibid., h. 517.

39. Ibid.

40. Lihat al-Thabariy, Jami' al-Bayan 'an Ta 'vvil ayyi al-Qur'an, Juz XV, (Cet. II ; Mesir : Syirkah Maktabah Musthafa alBabiy al-Halaby, 1945), h. 159-160.

41. Lihat al-Qurthubiy, Jami' al-Bayan, Juz V, (t.tp., t.th.), h. 310 dan Juz XV XVI/Jilid VIII (t, tp., t, th.), h. 283.

42. Lihat al-Nawawi, Shahih Muslim bi Syarh al-Nawawi, Jilid II, Juz IV, (Cet. II ; Beirut : Dar al-Fikr, 1978), h. 85,

43. Lihat al-Buchariy, Shihah al-Buchariy, juz I, (Cet. I ; Beirut : Dar al-Kutub alIslamiyyah, 1992), h. 190.

44. Lihat Salim Bahreisyi, Irsyad al-/bad ila Sabil al-Rasvad, (Darussegaf, t, th.), h. 428.

45. Lihat Gisan Hamdun, TaAir min Nasamat al-Quran Kaliatnat wa Bayan, (Cet. 11 ; Dadmaskus : al-Thaba'ah wa al-Tawzi wa al-Tarjarnah, 1986), h. 337. 
46. Lihat Bahrun Abubakar, Op. Cit., h. 193.

47. Lihat Ibid., h. 192.

48. Lihat Abu Daud, Sunan Ably Daud, Juz III, (Indonesia; Maktabah Dahlan, t, th.), h. 334.

49. Lihat Ibid.

50. Lihat Muhammad Syams, 'Atin a!-Ma 'bud bi Syarh Sunan Abi Daud, Jilid VII/13114 (Beirut : Dar al-Kutub alIslamiyyah, t, th.), h. 28.

51. Lihat Josef, CD, Wahyu Allah kepada Muhammad, terj., (Cet. I ; Jakarta : Pustaka Jaya, 1983). h. 335. 